\title{
Ignacio Olagüe y el origen de al-Andalus: Génesis y proceso de edición del proyecto negacionista
}

\author{
Ignacio Olagüe and the origins of al Andalus: genesis and edition process of the \\ negationist project
}

Alejandro GARCÍA SANJUÁN

Universidad de Huelva

sanjuan@dhis2.uhu.es

Recibido 2/4/2018. Revisado y aprobado para publicación 15/5/2018

Para citar este artículo: Alejandro GARCÍA SANJUÁN (2018), "Ignacio Olagüe y el origen de al-Andalus: Génesis y proceso de edición del proyecto negacionista” en Revista de Estudios Internacionales Mediterráneos, 24, $173-198$.

Para acceder a este artículo: https://doi.org/10.15366/reim2018.24.010

\section{Resumen}

Ignacio Olagüe (1903-1974) fue un historiador aficionado cuya celebridad procede, sobre todo, de haber cuestionado la idea de que el origen de al-Andalus esté vinculado a la conquista de la península ibérica por los musulmanes a partir del año 711. De acuerdo con sus ideas ultranacionalistas (fascistas), Olagüe pretendió demostrar que la formación de una sociedad árabe e islámica en la Península fue fundamentalmente, el resultado de causas internas. Pese a la condición amateur del autor y al carácter fraudulento de sus propuestas, sus ideas siempre han gozado de un cierto nivel de difusión, sobre todo en ámbitos extraacadémicos. Mi objetivo en este artículo se centra, sobre todo, en analizar el proceso de gestación y edición de su proyecto negacionista. Para ello me he servido del archivo privado del propio autor depositado en la Casa de Velázquez, a través del cual puede obtenerse una clara imagen de la consecución de sus objetivos historiográficos.

Palabras clave. Al-Andalus. Casa de Velázquez. Conquista islámica. Fascismo, Negacionismo. Olagüe.

\begin{abstract}
Ignacio Olagüe (1903-1974) was a Spanish amateur historian who achieved fame by calling into question the idea of the origins of al-Andalus being linked to the Islamic conquest of Iberia in 711
\end{abstract}


CE. According to his own ultranationalist (fascist) personal believes, Olagüe claimed that the existence of an Arab and Islamic society in Iberia was the result of an inner historical process and, therefore, must be simply understood as just one more achievement of the eternal Spanish genius. Despite the amateur status of the author and the blatantly fraudulent nature of his approach, his ideas have reached a certain level of diffusion in Spain, especially, but not only, in non-scholarly circles. This article is based on Olagüe's private archive, preserved at Casa de Velázquez (Madrid). My goal is to analyze the origins and edition process of his historiographical project, which were aimed mainly at the publication of a monograph work devoted to prove that Muslims never conquered Spain.

Key words. Al-Andalus. Olagüe. Islamic conquest. Denialism. Casa de Velázquez

\section{Introducción $^{1}$}

Ignacio Olagüe fue un historiador aficionado cuya notoriedad procede, sobre todo, de haber cuestionado la idea de que el origen de al-Andalus esté vinculado a la conquista de la península ibérica a comienzos del siglo VIII por contingentes árabes y beréberes que actuaban al servicio del Califato Omeya de Damasco, proponiendo, en su lugar, que la aparición de dicha entidad histórica se habría producido debido, fundamentalmente, a causas internas.

La condición amateur del autor se explica en base a dos circunstancias fundamentales. En primer lugar, su carencia de formación especializada, que le incapacitaba para la elaboración de propuestas historiográficas consistentes y basadas en una utilización metodológicamente rigurosa de los testimonios históricos. A este respecto, la exhaustiva crítica a la que ha sido sometida su producción escrita deja pocas dudas respecto a la naturaleza fraudulenta de sus ideas, basadas, en unos casos, en un uso parcial y sesgado de las fuentes, y en otros en el completo soslayo de las mismas (García San Juan 2013). Asimismo, debido a su carencia de vínculos estables con el mundo académico, en particular en España, si bien Olagüe logró establecer ciertas relaciones personales en el extranjero, las cuales facilitaron la difusión de su obra, como pondré de manifiesto en las páginas siguientes. El amateurismo del autor, por lo demás, queda de manifiesto en su ausencia de los principales repertorios de historiadores españoles contemporáneos ${ }^{2}$.

Pese a su naturaleza fraudulenta, las propuestas de Olagüe siempre han gozado de un cierto nivel de difusión, sobre todo en ámbitos extraacadémicos, la cual se ha incrementado en tiempos recientes de manera inusitada, debido a varios factores. La obra que contiene la versión más desarrollada de sus planteamientos, La revolución islámica en Occidente, publicada originalmente en 1974, ha sido reeditada en dos ocasiones por dos editoriales distintas, ambas cordobesas, en menos de quince años (2004 y 2017), lo cual revela la existencia de sectores interesados en

\footnotetext{
${ }^{1}$ 'Este trabajo es el resultado de una estancia como Investigador Residente en la Casa de Velázquez. Quiero manifestar mi sincero agradecimiento a los responsables académicos del centro por su acogida, así como al personal de la Biblioteca por su atención al facilitarme la consulta de la documentación'

${ }^{2}$ Olagüe no aparece registrado en Pasamar y Peiró 2002, ni tampoco en el Diccionario Biográfico Español, publicado por la Real Academia de la Historia (2011-2013), y que contiene 40.000 biografías de personajes relevantes de la historia de España pertenecientes a todos los ámbitos. En cambio, sí es reseñado en el repertorio de medievalismo hispánico: Sáez y Rosell 1976-1985, III, pp. 46-47.
} 
reactivar su vigencia ${ }^{3}$. Asimismo, en 2006 dichas ideas fueron respaldadas en España, por vez primera, desde el ámbito académico (González Ferrín 2006), hecho que marca un salto cualitativo de enorme relevancia en la legitimación de lo que, hasta esa fecha, no había pasado de ser mero entretenimiento para aficionados a las teorías conspiratorias sobre el pasado.

Como veremos en la parte final del artículo, la crítica historiográfica ha dejado constancia de la verdadera naturaleza historiográfica del fenómeno negacionista desde el mismo momento de su aparición. Por lo tanto, más que incidir en dicha labor crítica, en este trabajo pretendo, sobre todo, analizar su proceso de gestación y desarrollo. Para ello me he servido del fondo documental del propio autor depositado en la Casa de Velázquez (Madrid) desde 1974 e integrado por un total de 17 cajas de archivo, cada una de las cuales contiene un número variable de carpetas y manuscritos ${ }^{4}$. La documentación no está totalmente ordenada, aunque sí guarda cierta coherencia, al menos en algunos casos. Asimismo, las carpetas suelen llevar títulos en el exterior cuyos enunciados, a veces, solo coinciden de manera parcial con el contenido real. También he tenido la oportunidad de revisar la información registrada en la Fundación Juan March (Madrid) relativa a la edición de La revolución islámica en Occidente ${ }^{5}$.

Esta documentación revela datos hasta ahora inéditos sobre el proceso de elaboración del proyecto negacionista, datos que, a mi juicio, poseen un enorme interés para entender por qué y cómo las infundadas ideas de un historiador aficionado, carente de formación y criterio para interpretar las fuentes, han podido llegar a ser admitidas en ciertos sectores académicos. Una de las partes más importantes es la integrada por la correspondencia, tanto activa como pasiva, ya que, por fortuna, Olagüe tenía la costumbre, no sólo de guardar las cartas que recibía, sino también de hacer copias de las que mandaba. Esto permite obtener una imagen muy completa de sus contactos académicos internacionales, sobre todo franceses, así como de las relaciones que mantuvo con las distintas editoriales con las que intentó publicar, tanto en España como en Francia, principalmente. Dicha correspondencia apenas ha sido aprovechada hasta el momento, con la única excepción de B. Vincent ${ }^{6}$ y M. Fierro, que la utilizó parcialmente en la que fue la primera aproximación de importancia a la obra historiográfica de Olagüe y a su proceso de su recepción (Fierro 2009).

\section{La etapa anterior a la Guerra Civil}

\footnotetext{
${ }^{3}$ La primera de dichas reediciones fue realizada por la editorial cordobesa Plurabelle (2004), con la colaboración de la Junta de Andalucía, e incluía un prólogo del célebre historiador francés B. Vincent. La más reciente (2017) ha sido publicada por la también cordobesa Almuzara, cuyo propietario, el exministro Manuel Pimentel, reconvertido desde su salida del Gobierno en paladín de Blas Infante, es en la actualidad el principal promotor de las ideas de Olagüe: véase García Sanjuán 2018a.

${ }^{4}$ Esta documentación forma parte del legado de Olagüe en la Casa de Velázquez, que se produjo tras su muerte y del que forma parte, asimismo, la biblioteca del autor, integrada por más de dos mil libros y revistas y más de cien libros antiguos (siglos XVI y XVII). Véase “In Memoriam. D. Ignacio Olagüe Videla', Mélanges de la Casa de Velázquez, 10-1 (1974), p. 599; Delaunay 1994, p. 477.

${ }^{5}$ Agradezco a los responsables de la Fundación la autorización para la consulta del expediente.

${ }^{6}$ Vincent no indica haber utilizado el material perteneciente al archivo de Olagüe, si bien es algo que resulta evidente a la luz de su texto, en el que menciona su correspondencia y cita párrafos de sus cartas (Vincent 2004).
} 
La correcta comprensión de los planteamientos historiográficos de Olagüe exige tomar en consideración, en primer lugar, su formación y sus compromisos ideológicos. Lamentablemente, el período anterior a la Guerra Civil, el más importante en este aspecto, resulta ser la parte peor documentada de su vida en la documentación consultada.

Nacido en San Sebastián en 1903, parte de su juventud parece haber transcurrido en Francia, donde su madre (Consuelo Videla y Elio) se trasladó a vivir tras enviudar y casarse en segundas nupcias en 1919 con Emilio Rancés y de la Gándara, Marqués de Casa Laiglesia ${ }^{7}$. Cursó estudios de Bachillerato en los Jesuitas de Hernani y en Toulouse ${ }^{8}$, y posteriormente se habría licenciado en Derecho en la Universidad de Valladolid ${ }^{9}$, donde consta que recibió cierta formación histórica, aunque no parece haber destacado especialmente en ella ${ }^{10}$.

Antes de 1936 su actividad más conocida se desarrolla en el Museo Nacional de Ciencias Naturales de Madrid, donde durante doce años (1924-1936) fue uno de los colaboradores del castellonense José Royo Gómez (1895-1961), el más célebre geólogo y paleontólogo español de la época, exiliado en Colombia y Venezuela tras la Guerra Civil (Truyols y otros, 2004). La relación entre ambos debió ser muy estrecha, pues mantuvieron contacto hasta la muerte de quien Olagüe siguió considerando, durante muchos años, como su 'maestro' 11 .

A lo largo de esta primera etapa, la Historia no parece haber sido un centro de interés principal para Olagüe, cuya vocación historiográfica sólo empezará a manifestarse a partir del final de la Guerra Civil. En efecto, su producción escrita en estos años se vincula, sobre todo, al ámbito de la literatura y el teatro, con obras como Martín Alegret, el organero: novela sobre un tema musical (1928) o El demonio y las yemas de San Leandro (1933).

Aunque las circunstancias vividas por Olagüe durante la Guerra Civil no se conocen con exactitud, los testimonios acreditan que atravesó por dificultades, sin duda relacionadas con su militancia política, un aspecto del que, sin embargo, hay muy poco rastro en la documentación. Entre dichos testimonios se encuentra un ejemplar original del panfleto que contiene el 'Manifiesto político' de

\footnotetext{
${ }^{7}$ ABC, 17 Abril 1919; El Sol, 17 Abril 1919. La casa de Olagüe en San Sebastián se llamaba 'Villa Consuelo', sita en Avda. Satrústegui, 5, frente a la playa de La Concha.

8 Caja 1. Carpeta 'Manuscritos Olagüe', contiene hoja manuscrita titulada 'Cronología', con anotaciones correspondientes a los años 1914-1923. Respecto al año 1919 anota: 'Toulouse - Examen Bachillerato' y respecto a 1920, 'Toulouse, Rue des Trente Six Ponts. Título 1er Grado Bachiller'. Caja 13. Carpeta 'Críticas de periódicos', contiene carta de invitación del Rector de la Universidad de Toulouse fechada el 17 Mayo 1951, en la que le indica: 'nous savons que vous avez fait a Toulouse une partie importante de vos études'.

${ }^{9}$ Así lo indica en el CV que Olagüe presentó para solicitar las Ayudas a la Investigación de la Fundación Juan March en 1960. Véase Caja 4. Carpeta 'Solicitud a la Fundación Juan March'. Sin embargo, en su documentación no se conserva ningún certificado relativo a su titulación académica.

${ }^{10}$ Caja 7. Carpeta sin título, contiene papeleta de examen de la Facultad de Filosofía y Letras, Curso académico 1921 1922, de la asignatura Ha de España (general). La calificación, obtenida en la convocatoria de Junio, fue 'Aprobado'. Fechado el 6 Junio 1922.

${ }^{11}$ Caja 8. Carpeta 'Correspondencia científica', contiene correspondencia entre ambos relativa a los años 1947-1960. Acompaña una nota que dice 'Cartas (algunas) de mi maestro José Royo Gómez, emigrado, muerto en el destierro y escritas desde América'.
} 
las JONS ${ }^{12}$, así como una carta de Juan de Alustiza fechada en 1940 en la que alude de manera explícita a la ideología fascista de Olagüe, al que califica como 'zahorí político'13:

'Sabes que en este momento en que los acontecimientos políticos marchan a cien a la hora es bueno recordar aquellas viejas discusiones del "Guria"14 allí (sic) por el año 28 en las que tú con una intuición de zahorí político nos descubrías un futuro fascista. Para mi tu no eres un camisa vieja, perteneces a su prehistoria, algo así como el antiguo testamento del fascismo. Saludo pues al profeta Olagüe y espero con avidez sus "Opiniones sobre la decadencia española".

Otra referencia relevante al respecto figura en la carta enviada en 1971 a Jesús de la Serna, director del diario Informaciones, en la que Olagüe rememora brevemente las circunstancias vividas en 1937 junto al padre del mismo ${ }^{15}$ y otros falangistas ${ }^{16}$ :

'Mi distinguido amigo: Lo he sido de su padre. Le he conocido antes de la guerra civil, cuando era redactor de Informaciones, con el Tebid (sic) Arrumi $^{17}$. En compañía del ya difunto Tito Menéndez hemos pasado juntos momentos aciagos en Salamanca, en la primavera del año 37'.

Tales 'momentos aciagos' se refieren, sin duda, al arresto en Salamanca del líder falangista Manuel Hedilla y un grupo de sus seguidores el 25 de abril de 1937, unos días después del 'Decreto de Unificación' promulgado por Franco en dicha ciudad (Casanova 2007: pp. 350-353). Ello explicaría otra circunstancia, hasta ahora desconocida, la del encarcelamiento de Olagüe en la prisión donostiarra de Ondarreta, tal y como él mismo indica en una anotación realizada en la cubierta de uno de sus manuscritos ${ }^{18}$ :

'Trabajo realizado en gran parte en la cárcel de Ondarreta (julio y agosto 1938) sirviéndome de amanuense un telegrafista de San Sebastián, compañero de celda, fusilado por no haber cursado al gobernador militar el miércoles o jueves anterior al 18 de agosto un telegrama del General Mola pidiéndole su adhesión al movimiento o algo parecido, como si estas cosas se hacían a la luz del día, de la prensa y de los telegrafistas'.

\footnotetext{
${ }^{12}$ Caja 8. Carpeta 'Temas políticos'. Fechado en Madrid en Diciembre de 1931. La fundación de las JONS fue anunciada en Octubre de 1931 en el semanario La conquista del Estado, creado en Marzo de ese mismo año por Ledesma Ramos (Gallego 2005, pp. 106-107).

${ }^{13}$ Caja 7. Carpeta 'Correspondencia literaria I'.

${ }^{14}$ Se trata, sin duda, de un restaurante vasco. En Bilbao existe desde hace tiempo uno con ese nombre, aunque ignoro si puede tratarse del mismo mencionado en la carta.

${ }^{15}$ Se trata del falangista Víctor de la Serna y Espina (1896-1958), hijo de la escritora Concha Espina, nombrado director de Informaciones tras el final de la Guerra Civil.

${ }^{16}$ Caja 7. Carpeta 'Les arabes. Critiques et Lettres'. Citada por Fierro 2009, p. 340.

17 Víctor Ruiz Albéniz (1885-1954), sobrino del célebre compositor Isaac Albéniz (1860-1909) y periodista español conocido por el seudónimo del Tebib Arrumi ('el médico cristiano', en árabe), debido, al parecer, a que actuó como tal en Marruecos durante el Protectorado español. Padre de José Mạ Ruiz-Gallardón (1927-1986) y abuelo de Alberto Ruiz-Gallardón (n. 1958).

${ }^{18}$ Caja 14. Ondarreta era, precisamente, el barrio en el que estaba 'Villa Consuelo', la casa donde Olagüe siempre pasó temporadas y que tomaba su nombre de su madre.
} 
Desconocemos la dimensión exacta de los efectos que los problemas vividos durante la guerra pudieron llegar a causarle, aunque hay algunas referencias a la pérdida de libros y documentos ${ }^{19}$. Sea de ello lo que fuere, lo cierto es que Olagüe parece haber gozado tras la guerra de una posición acomodada, circunstancia de la que existen claras evidencias. Una de ellas consiste en la localización de su domicilio habitual madrileño, sito en pleno barrio de Salamanca, en la calle Serrano, a lo que se añadía la casa en San Sebastián más la que se construyó, al final de su vida, en Javea (Alicante), donde murió en $1974^{20}$. La documentación incluye referencias que indican la misma realidad, tales como sus habituales veraneos en el balneario pirenaico de Panticosa (Huesca) y en Mallorca, así como los viajes frecuentes a París y otros lugares de Francia y de Europa $^{21}$. Asimismo, como es sabido, Olagüe poseía una importante biblioteca, que incluía varias ediciones de obras de Quevedo del siglo XVII (Moll 1980, pp. 457-494), y a la bibliofilia se añade su afición por la gastronomía, típica de sus orígenes vascos, de la que existe también constancia en la documentación preservada ${ }^{22}$. En definitiva, fue una persona que, como él afirmaba de sí mismo, se dedicó de forma exclusiva a lo que calificaba de 'investigación científica' y a la publicación de obras de carácter literario e histórico ${ }^{23}$, no conociéndosele ninguna otra actividad profesional ${ }^{24}$.

Sin duda, esa acomodada posición no fue ajena a otra de las facetas más importantes del personaje, su importante red de amistades, contactos y relaciones personales, prácticamente en todos los ámbitos: político-diplomático, periodístico, literario, medios de comunicación e incluso artístico $^{25}$ o militar ${ }^{26}$. Entre los documentos preservados se encuentran elementos que dan idea del nivel de las relaciones de Olagüe como, por ejemplo, tarjetas de invitación a cócteles organizados por personalidades francesas en Madrid como Le Comte Clauzel, Ministre Plénipotentiaire, o el Embajador de Francia y la Baronne de la Tournelle ${ }^{27}$. Se trata de un aspecto

\footnotetext{
${ }^{19}$ Caja 7. Carpeta 'Correspondencia Literaria I'. Fechada el 16 Enero 1940, mecanografiada, membrete de 'Legación de España. Caracas'. La carta está firmada, pero sin indicación del nombre del firmante: 'Me alegro que hayas salvado algo de tu casa y de tus libros, sobre todo, pues es lo que más vale'. Caja 8. Carpeta 'Correspondencia científica', postal de Robert Aitken fechada el 10 Enero 1940, manuscrita (en español): 'Lamento sinceramente su pérdida irreparable de libros y documentos'.
}

${ }^{20}$ Caja 9. Carpeta 'Flammarion', carta fechada en Javea el 2 Mayo 1972, mecanografiada (dos folios), Olagüe informa a su interlocutor (Henri Noguères) de que, 'huyendo de los inconvenientes de la gran ciudad', se ha construido una casa en un campo de viñas situado a $1 \mathrm{~km}$. de distancia de dicha población alicantina y que está allí instalado desde el mes de Octubre anterior, si bien sigue conservando su apartamento madrileño.

${ }^{21}$ Caja 9. Carpeta 'Flammarion', carta fechada en San Sebastián el 26 Agosto 1966, Olagüe informa a su interlocutor de que tiene previsto hacer 'un viaje de estudio a Grecia en el mes de octubre'.

${ }^{22}$ Caja 9. Carpeta 'Guisos y figones', incluye un documento mecanografiado de cuatro folios con membrete de las I Jornadas Hispano-Francesas de Gastronomía. Vinos de España en la Gastronomía Internacional, celebradas en San Sebastián del 9 al 17 de Septiembre de 1967. La ponencia de Olagüe, contenida en dicho documento, lleva por título '¿Influencias orientales en la preparación de chipirones?'. Asimismo, dicha Caja contiene la carpeta original de las Jornadas, con el citado membrete.

${ }^{23}$ Caja 4. Carpeta 'Solicitud a la Fundación Don (sic) Juan March'.

${ }^{24}$ La Caja 9. Carpeta 'Cuentas Mayfe', contiene abundante documentación económica cuyo estudio permitiría apreciar los beneficios que generaban a Olagüe sus publicaciones, charlas y conferencias.

${ }^{25}$ Caja 7. Carpeta 'Correspondencia Literaria I', incluye nota de acuse de recibo de Joaquín Argamasilla (1905-1985), que fue Director General de Cinematografía y Teatro durante la dictadura, fechada en Madrid el 29 Mayo 1953 (mecanografiada), con membrete de dicha institución, en la que se despide apelando a 'nuestra buena y antigua amistad'.

${ }^{26}$ Caja 7. Carpeta 'Correspondencia Literaria I', nota de acuse de recibo de La decadencia española del General Antonio Mata Aranda (1888-1979), fechada en Madrid el 10 Enero 1944, manuscrita.

${ }^{27}$ Caja 9. Carpeta 'Cuentas Mayfe'. 
que en absoluto carece de interés a la hora de comprender la difusión de su obra historiográfica, ya que, como veremos a continuación, Olagüe siempre se sirvió de sus contactos como palanca principal para la promoción de sus trabajos y publicaciones ${ }^{28}$.

\section{Origen del proyecto negacionista: La decadencia española}

El final de la guerra supone el comienzo de una actividad historiográfica que ocupó buena parte de su vida, si bien, como ya se ha dicho, Olagüe carecía de formación como historiador y nunca se integró en las estructuras académicas españolas, circunstancia que supo utilizar en su favor de una forma muy hábil, como veremos más adelante.

La génesis de sus ideas sobre el origen de al-Andalus se encuentran en su primera obra historiográfica, La decadencia española: ensayo para la rectificación de la historia de España, cuya versión inicial, incompleta (integrada por un solo volumen), se publicó en San Sebastián en 1939, meses después del final de la Guerra Civil. Aunque en este primer volumen, Olagüe no llega a desarrollar aún las ideas que, tiempo más tarde acabarían, dándolo a conocer, La decadencia española resulta de interés debido, sobre todo, a que revela que sus planteamientos sobre el pasado peninsular son parte integral de su ideología fascista ${ }^{29}$, tal y como ya pusieron de manifiesto tanto J. Rodríguez Puértolas (Rodríguez Puértolas 2008, II, pp. 833-834) como M. Fierro. A esta orientación obedece la noción de 'rectificación', en función de la cual concibe la Historia como manual de autoayuda para recuperar la perdida autoestima nacional. De hecho, La decadencia española debe ser valorada como un referente de primer orden en la conformación de una historiografía fascista en España, si bien se trata de un aspecto que no puedo desarrollar en este trabajo.

En estricta coherencia con el sentido de su propuesta, la obra fue reseñada muy elogiosamente en la prensa de la época por acreditados falangistas como J. Ma de Areilza $^{30}$, su amigo J. Miquelarena ${ }^{31}$ y F. Guillén Salaya ${ }^{32}$, así como por el carlista J. Etayo Zalduendo ${ }^{33}$, J. Ma Salaverría ${ }^{34}$,

\footnotetext{
${ }^{28}$ Caja 9. Carpeta 'Cuentas Mayfe'.

${ }^{29}$ Los vínculos fascistas de Olagüe permiten poner de manifiesto, una vez más, la incapacidad de sus seguidores actuales para comprender la crítica historiográfica. Así lo revela el texto siguiente: 'Dado que, por lo visto, este señor era falangista, esa falacia del consecuente se arma fácilmente para consumo de incautos: como Olagüe era falangista y negó la invasión, todo aquel que niegue la invasión es falangista': González Ferrín 2017, p. 234. En realidad, se trata de la enésima pose de los seguidores actuales de Olagüe para seguir fomentando su ya bien acreditado victimismo. En efecto, la crítica a los epígonos del autor vasco no incluye, en ningún caso, la calificación de los mismos como 'falangistas'. Parece obvio, por lo tanto, de qué lado caen las actitudes falaces.

${ }^{30}$ Diario Vasco, 8 Febrero 1940. Sobre Areilza, véase Rodríguez Puértolas 2008, I, pp. 357-360 y II, pp. $854-859$.

${ }^{31} A B C, 2$ Febrero 1940. Al igual que hizo más tarde respecto a otra obra de Olagüe, This is Spain: ABC, 28 Junio 1954. Caja 13. Carpeta 'Críticas de periódicos', contiene carta de Miquelarena fechada en Londres el 25 Junio 1954 , mecanografiada, relativa a dicho libro. Autor conocido, entre otros motivos, por ser uno de los letristas de Cara al sol, el himno de Falange: véase Rodríguez Puértolas 2008, I, p.138.

32 Informaciones, 23 Noviembre 1939. Sobre Guillén Salaya . Véase Rodríguez Puértolas 2008, I, pp. 116 y 118-119.

${ }^{33}$ Diario de Navarra, 5 Agosto 1940.
} 
M. Fernández Almagro (uno de los grandes próceres académicos del franquismo $)^{35}$ y J. Ma Belderrain ${ }^{36}$. Olagüe también envió dos ejemplares al entonces director de La Vanguardia, Luis de Galinsoga, el cual acusa recibo de los mismos y le anuncia que se ocupará de que aparezca en su diario 'la oportuna crítica de tan interesante y meritísimo libro' ${ }^{37}$.

Se conserva parcialmente la correspondencia que Olagüe mantuvo con los autores de algunas de estas reseñas, entre ellos José Mạ de Areilza (1909-1998), el cual elogia con entusiasmo la sintonía de la obra con la causa fascista ${ }^{38}$ :

'Si vivieran los grandes precursores, José Antonio y Ledesma, aprobarían de lleno su propósito. Su libro está en la mejor línea de fidelidad a los fines históricos de la revolución nacional'.

No fue la única calurosa felicitación que recibió Olagüe desde esa perspectiva. Como es sabido, $L a$ decadencia española está dedicada al fundador de las JONS, Ramiro Ledesma Ramos (1905-1936), 'muerto por el resurgimiento de España' y 'en testimonio de eterna amistad' ${ }^{39}$. Este hecho parece haber sido el motivo principal de la carta que le envía Enrique Compte Azcuaga ${ }^{40}$, el cual se presenta a sí mismo como antiguo secretario de Ledesma y uno de los nueve fundadores de las $\mathrm{JONS}^{41}$, trasladándole que, a través del 'camarada Santiago Montero Díaz' ${ }^{42}$, ha tenido noticia de su libro, así como de la 'espléndida y honrosa' dedicatoria que contiene. En un tono similar se expresa el conocido periodista carlista navarro Jesús Etayo Zalduendo (1894-1951): 'mi felicitación y mis alientos por y para su patriótica tarea ${ }^{\prime 43}$.

La correspondencia muestra que también se ocupó de difundir La decadencia española en medios académicos, haciéndola llegar a la Real Academia de la Historia que, a través de su secretario, acusaba recibo de la obra 'con la que justifica su docta actividad y el renombre que disfruta en este linaje de estudios' ${ }^{\prime 4}$.

\footnotetext{
${ }^{34}$ España, 30 Noviembre 1939. Autor que Fusi 1999, p. 54, caracteriza como «maurrasiano y pre-fascista».

${ }^{35} A B C, 23$ Noviembre 1939. Sobre Fernández Almagro, véase su entrada en la Web de la Real Academia de la Historia: http://www.rah.es/melchor-fernandez-almagro/. Acceso 20 Septiembre 2017.

${ }^{36}$ La Voz de España, 10 Octubre 1940.

${ }^{37}$ Caja 7. Carpeta 'Correspondencia Literaria I'. Carta fechada en Barcelona el 2 Diciembre 1939.

${ }^{38}$ Caja 7. Carpeta 'Correspondencia literaria I'. Nota fechada en Algorta (Vizcaya) el 20 Febrero 1940, mecanografiada (a doble cara).

${ }^{39}$ El propio Olagüe 1950-1951, I, p. 9, narra en el prólogo de la versión completa de la obra ('Confesión al lector') que conoció a Ledesma en Madrid en 1930, en la galería de arte que fundó junto a los amigos con quienes editaba $L a$ Gaceta Literaria. De él afirma lo siguiente: 'me dejó estupefacto y maravillado al exponerme su pretensión de fundar un partido político', y añade: 'nos hicimos amigos y conversamos bastante en aquellos días'.

${ }^{40}$ Caja 7. Carpeta 'Correspondencia Literaria I'. Nota fechada en Madrid el 27 Noviembre 1939.

${ }^{41}$ Figura como miembro del 'Comité de Secretariado' de las JONS en el 'Manifiesto político' del que Olagüe poseía un ejemplar, como he dicho anteriormente.

${ }^{42}$ Santiago Montero Díaz (1911-1985), Catedrático de Historia Medieval en la Universidad de Murcia en 1936, fue comunista, posteriormente fascista (seguidor de Ledesma), luchó en la Guerra Civil en el bando franquista, fue admirador de Hitler, siendo inhabilitado de su cátedra por el franquismo y exiliándose en Chile. Véase Pasamar y Peiró 2002, pp. 422-424.

${ }^{43}$ Caja 7. Carpeta 'Correspondencia Literaria I'. Nota fechada en Pamplona el 14 Marzo 1940.

${ }^{44}$ Caja 7. Carpeta 'Correspondencia Literaria I'. Nota fechada en Madrid el 9 Enero 1940.
} 
Datan, asimismo, de esta época los primeros intentos de Olagüe por establecer contactos con el mundo académico francés, tal y como sugiere la nota de acuse de recibo del célebre hispanista Marcel Bataillon (1895-1977) ${ }^{45}$, tendencia que se iría acentuando con el paso del tiempo.

Más de diez años después, Olagüe pudo publicar la segunda y definitiva versión de La decadencia española, mucho más amplia que la anterior, integrada por cuatro volúmenes que abarcan más de 1500 páginas. En esta ocasión fue editada entre 1950-1951 por Mayfe, propiedad entonces de dos amigos del autor, Manuel Conde López y Federico Sánchez Torre ${ }^{46}$. El propio Olagüe afirmaba tiempo después que dicha obra le había ocupado doce años de su vida, desde 1938 a 1950, 'esfuerzo llevado a cabo sin ayuda alguna, ni del estado, ni de una entidad particular' ${ }^{47}$.

Por vez primera, Olagüe pudo desarrollar sus ideas historiográficas de forma completa, incluyendo las relativas a lo que ya denomina la 'revolución islámica' ${ }^{48}$. En ese sentido, La decadencia española pone de manifiesto que su concepto de al-Andalus como producto histórico fundamentalmente autóctono y cuyo origen, por lo tanto, era ajeno a una acción de conquista por contingentes árabes y beréberes, forma parte de su 'rectificación' ultranacionalista de la historia de España y es inseparable de ella, no pudiendo entenderse correctamente al margen del marco ideológico fascista del que surge.

Al igual que con la primera versión, Olagüe da la máxima difusión a la obra en la prensa ${ }^{49}$, de nuevo con reseñas de falangistas como Santiago Magariños ${ }^{50}$ y Federico de Urrutia ${ }^{51}$, y también de otros como el ya citado Fernández Almagro ${ }^{52}$, Tristán la Rosa ${ }^{53}$ y Ángel Dotor ${ }^{54}$.

Asimismo, otro de los instrumentos que utilizó para promocionarla fueron sus contactos en el ámbito diplomático, en el que tuvo muy buenas relaciones, seguramente gracias a su cercana amistad con su paisano Luis Mạ de Lojendio (1907-1987) ${ }^{55}$, primer responsable de la Oficina de Información Diplomática desde 1946 y que, con posterioridad, se hizo monje, llegando ser elegido Abad del Valle de los Caídos, de manera que fue el encargado de recibir el cuerpo de Franco para

\footnotetext{
${ }^{45}$ Caja 7. Carpeta 'Correspondencia Literaria I'. Nota fechada en París el 7 Diciembre 1939, manuscrita (en español), membrete del Institut d'Études Hispaniques de l'Université de Paris.

${ }^{46}$ Caja 9. Carpeta 'Cuentas Mayfe', carta del propietario posterior de Mayfe, Luis Moretón, a Olagüe, fechada en Madrid el 26 Abril 1967, lo menciona explícitamente: ‘sus antiguos amigos y paisanos los Sres. Conde López y Sánchez Torre'.

${ }^{47}$ Véase el CV que acompaña su solicitud a las Ayudas a la Investigación de la Fundación Juan March (citado más adelante).

${ }^{48}$ Olagüe 1950-1951, II, capítulo XIV ('La revolución islámica').

${ }^{49}$ Caja 7. Carpeta 'Críticas de periódicos', contiene originales de todas las reseñas.

${ }^{50}$ El Correo Literario, 15 Mayo 1951.

${ }^{51}$ Hierro, 17 Enero 1953.

${ }^{52} A B C, 8$ Junio 1952.

${ }^{53}$ La Vanguardia, 12 Abril 1951.

${ }^{54}$ El Telegrama del Rif, 24 Mayo 1951; Patria, 3 Junio 1951; Menorca, 23 Junio 1951; Nuevo Correo (Buenos Aires), 10 Noviembre 1951.

${ }^{55}$ Caja 13. Carpeta 'Críticas de periódicos', incluye carta de Lojendio, fechada en Madrid el 4 Julio 1951, con membrete de 'Ministerio de Asuntos Exteriores. El Jefe Técnico de la Oficina de Información Diplomática'.
} 
su entierro ${ }^{56}$. Entre las personalidades de más alto nivel diplomático en la correspondencia de Olagüe se encuentra otro falangista vasco, el bilbaíno José F. de Lequerica (1890-1963), entonces embajador en Washington, el cual se compromete a difundir el libro ${ }^{57}$, al igual que Antonio $\mathrm{C}$. Zabalza, perteneciente a la misma embajada ${ }^{58}$, Antonio Ma Aguirre, embajador en la RFA ${ }^{59}$, y su 'antiguo y buen amigo', también vasco, Germán Baraibar, a la sazón encargado de negocios en $\mathrm{Cuba}^{60}$. Probablemente, Olagüe utilizó estos contactos diplomáticos para hacer llegar su libro al dictador portugués Oliveira Salazar, como consta en la documentación, lo que prueba el enorme despliegue realizado por el autor en este ámbito político-diplomático ${ }^{61}$.

Pero Olagüe tampoco descuida el plano cultural y académico y, en este caso, sabemos que acudió al literato catalán Guillermo Díaz-Plaja (1909-1984), el cual le traslada su muy favorable opinión: 'su trabajo me parece sencillamente impresionante y que creo que es absolutamente imprescindible para plantear el problema general de la cultura española sobre bases completamente nuevas'. De este modo, le anuncia su intención de promocionarla: 'Pienso ocuparme de ella a través de mi emisión literaria de Radio Nacional de España ${ }^{62}$, cosa que, en efecto, hizo a los pocos días, como consta en la propia documentación ${ }^{63}$.

Otra de las personalidades del ámbito literario y periodístico que estaba en su círculo de conocidos era Juan Estelrich (1896-1958) quien, entre otras cosas, fue desde 1951 delegado permanente de España en la Unesco, una institución con cuyos representantes franceses Olagüe tomaría contacto a partir de finales de la década de 1950, como veremos más adelante. Estelrich le expresa su amistad haciéndole saber que se ha mantenido siempre al tanto de su situación a través de Lojendio, sumándose, asimismo, a la labor de promoción de la obra en la prensa: 'cuenta conmigo para la propaganda de tu libro en nuestro Diario y en su Suplemento Dominical. Para el artículo en el semanario ${ }^{64}$ entrega un ejemplar para el Sr. Vázquez Zamora en nuestra delegación en Madrid'65.

\footnotetext{
${ }^{56}$ Véase Fernández 2016, pp. 213-228.

${ }^{57}$ Caja 13. Carpeta 'Críticas de periódicos'. Carta fechada en Washington el 9 Enero 1951, mecanografiada, membrete de la Embajada.

${ }^{58}$ Caja 13. Carpeta 'Críticas de periódicos'. Carta fechada en Washington el 9 Enero 1951, mecanografiada.

59 Caja 9. Carpeta 'Cuentas Mayfe', dos cartas de A. M. Aguirre fechadas en Bonn el 6 y el 18 Noviembre 1954, membrete de 'El Embajador de España', denotando un trato muy familiar con el autor, al que se dirige como 'querido Ignacio'.

${ }^{60}$ Caja 13. Carpeta 'Críticas de periódicos'. Carta fechada en La Habana el 12 Noviembre 1951, mecanografiada, membrete de Embajada de España en La Habana.

${ }^{61}$ Caja 9. Carpeta 'Cuentas Mayfe', carta de Mayfe fechada en Madrid el 26 de Julio 1951 (firmada por F. Sánchez Torre): 'celebro que hayas tenido la satisfacción de recibir esas líneas autógrafas de Oliveira Salazar. Demuestra ser un hombre sencillo y correcto. No me cabe duda de que leerá con interés tu libro'. En esas fechas, Salazar ocupaba interinamente la Presidencia de la República de Portugal. No he podido localizar esta nota entre la documentación consultada.

${ }^{62}$ Caja 13. Carpeta 'Críticas de periódicos'. Carta fechada en Barcelona el 5 Mayo (año tachado), mecanografiada.

${ }^{63}$ Caja 13. Carpeta 'Críticas de periódicos'. Carta de Radio Nacional de España fechada en Barcelona el 30 Mayo 1951 , dando cuenta del comentario realizado por Díaz-Plaja en la emisión, el día anterior, de 'La pluma al viento'.

64 Ignoro a qué publicación se refiere. En Caja 7. Subcarpeta sin título, se incluye una carta de Estelrich fechada en Barcelona el 26 Junio 1946, con membrete de Editorial Alpha, SA, manuscrita (un folio, a doble cara), adjunta a un documento mecanografiado (cinco folios) titulado 'Proyecto para la publicación de un semanario en Madrid', sin duda obra del propio Olagüe, en el que se indica que el título del mismo podría ser 'Ni más, ni menos'.

${ }^{65}$ Caja 13. Carpeta 'Críticas'. Dos cartas fechadas en 1951 en Tánger, donde Esterlich era director del diario España.
} 
A medias entre el mundo diplomático y cultural habría que situar al irlandés Walter Starkie (18941976), al que Olagüe también envió la obra, como revela la carta de acuse de recibo fechada en Madrid el 5 Marzo 1951. Starkie fue fundador y director entre 1940 y 1954 del British Institute en Madrid, organismo dependiente del British Council (cuyo membrete lleva la citada carta).

\section{Primeras tentativas de elaboración de un proyecto negacionista independiente}

Tras publicar La decadencia española, el objetivo principal de Olagüe se centra en la elaboración de una obra monográfica dedicada a desarrollar de forma extensa sus ideas sobre el origen de la cultura árabe e islámica en la Península, una obra que, como él mismo afirma, habría comenzado a escribir en el año $1958^{66}$. Ello significa que hubo de esperar once años hasta poder verla publicada, si bien, al igual que en el caso de La decadencia española, habría dos versiones de esa obra.

La primera versión apareció en Francia, país con el que tenía antiguos vínculos personales y familiares y con cuyos medios académicos ya establece contactos intensos desde la década de 1950, entre ellos, por ejemplo, el geógrafo Jean Sermet (1907-2003) ${ }^{67}$. Esos contactos, de hecho, se irán intensificando de manera progresiva en cantidad y calidad como revela, sobre todo, su relación con Fernand Braudel (1902-1985) y también con los responsables de la revista Diogène, editada en París por la Unesco, primero Roger Caillois (1913-1978) y más tarde Jean d'Ormesson $(1925-2017)^{68}$, extendiéndose, incluso, a otros sectores ${ }^{69}$. De este modo, ya a comienzos de la década siguiente Olagüe llegaría a integrarse en la International Society for the Comparative Study of Civilizations, creada por Pitirim Sorokin (1889-1968) y Arnold J. Toynbee (1889-1975), lo cual debe considerarse, sin duda, como su éxito académico más importante ${ }^{70}$.

La primera tentativa la realiza ante Librairie Plon, editorial parisina con la que entra en contacto, aparentemente, en 1959, cuando, en realidad, su proyecto, titulado 'La Mosquée de Cordoue', no estaba ni siquiera concluido. La editorial lo remitió a Philippe Ariès (1914-1984), director de una de

\footnotetext{
${ }^{66}$ Caja 9. Carpeta 'Flammarion. Ignacio Olagüe. La Mosquée de Cordoue et la révolution islamique'. Carta a H. Noguères fechada el 25 Marzo 1971.

${ }^{67}$ Caja 13. Carpeta 'Críticas de Periódicos', contiene correspondencia con Sermet, casi toda con membrete de Cabinet du Prefet de la Haute-Garonne. Sobre este autor, muy vinculado con Andalucía, véase Bosque Maurel 1981, pp. 11-42.

${ }^{68}$ Su correspondencia se encuentra dispersa. Caja 7. Carpeta 'Correspondencia Literaria II', contiene amplio dossier relativo a dicha revista, con correspondencia que se remonta a 1957. Otras cartas en Caja 7. Carpeta 'Cartas' y Caja 10. Carpeta 'Mezquita'.

${ }^{69}$ Caja 7. Carpeta 'Correspondencia Literaria II', contiene carta de Mademoiselle Cassin fechada en París el 23 Enero 1967 (manuscrita, un folio), que escribe de parte del célebre cineasta Abel Gance (1889-1981), a quien Olagüe había dedicado en 1960 un ejemplar de su Diario de a bordo de Juan de la Cosa (1958). La remitente indica que Gance pretende llevar a las pantallas la figura de Cristóbal Colón y, para ello, quiere entrar en contacto con Olagüe, cuya respuesta favorable está fechada en Madrid el 28 Enero 1967.

${ }^{70}$ Caja 7. Carpeta 'Anderle', contiene abundante documentación sobre su participación en dicha sociedad, así como correspondencia con el propio Sorokin y, sobre todo, con Othmar Anderle, secretario de la sociedad y, posteriormente, presidente.
} 
sus colecciones, el cual lo rechazó por razones que el responsable de la editorial (Charles Orengo, Directeur littéraire) explicaba a Olagüe con las palabras siguientes ${ }^{71}$ :

'Je ne parle pas, volontairement, de votre projet sur "La Mosquée de Cordoue"; vous avez eu un entretien avec Monsieur Philippe Ariès, qui est directeur de la seule collection où un tel ouvrage puisse être inséré et je crois qu'il vous a fait part très précisement de son point de vue: il lui est impossible de se prononcer sur un projet, intelligent certes, mais que ne donne pas une idée suffisante de l'ouvrage auquel il pourrait aboutir. II faut donc un manuscrit définitif pour que Monsieur Ariès puisse nous demander d'établir un contrat. Je ne sais finalement si, entre nous, les ponts sont coupés: ils le seront si vous considérez qu'ils doivent l'être. Autrement c'est bien volontiers que nous étudierons le manuscrit de "La Mosquée de Cordoue", en vous promettant cette fois une réponse plus prompte'.

Al año siguiente, Olagüe pone en marcha una segunda iniciativa para sacar adelante el proyecto, ahora en España, presentándose como candidato a unas 'Ayudas a la Investigación' que, desde años atrás, convocaba la Fundación Juan March. La memoria de su proyecto llevaba por título 'La Revolución islámica en la Alta Edad Media Española ${ }^{72}$, muy similar, por lo tanto, al que tendría la edición definitiva de su manifiesto negacionista (La revolución islámica en Occidente), publicado por la misma institución en 1974. Dos de los miembros del jurado encargado de otorgar las ayudas se dirigieron con posterioridad a Olagüe de forma personal lamentando la decisión, lo cual revela, probablemente, una cierta relación o conocimiento previo entre ellos: Fernández Almagro, designado por la Real Academia de la Historia ${ }^{73}$ y J. Camón Aznar (1898-1979), Catedrático de Historia del Arte Medieval en la Universidad de Madrid y miembro del jurado a propuesta del $\mathrm{CSIC}^{74}$.

Como veremos más adelante, Olagüe utilizaría años después ante $\mathrm{F}$. Braudel esta negativa de la Juan March para articular un discurso en el que se presenta a sí mismo como víctima del 'sistema', es decir, alguien marginado en el mundo académico español de la época debido a la naturaleza excesivamente innovadora de sus ideas, viéndose obligado a trabajar en circunstancias adversas, sin ayudas de ninguna clase y debiendo afrontar por sus propios medios todos los costes generados por su esfuerzo.

En realidad, según ya hemos visto, lejos de lo que pretendía, Olagüe era una persona extraordinariamente bien conectada, con relaciones importantes a todos los niveles, político, diplomático, mediático y académico. De hecho, dada su falta de cualificación académica como historiador e investigador, fue solo el recurso permanente y sistemático a dichos contactos personales lo que le permitió publicar la mayoría de sus trabajos historiográficos. Así pues, su discurso victimista revela una autoimagen personal fuertemente distorsionada, si es que no se trata de una mera impostura. Por otra parte, resulta muy revelador comprobar que ese mismo

\footnotetext{
${ }^{71}$ Contra lo que suele ser habitual, en este caso solo se conservan las cartas de la editorial (dos), pero no las del propio Olagüe. Ambas fechadas en París, el 21 Julio y el 31 Diciembre de 1959, respectivamente. Caja 10. Carpeta 'Mezquita'.

${ }^{72}$ Caja 4. Carpeta 'Solicitud a la Fundación Don (sic) Juan March', incluye tarjeta de la Fundación con acuse de recibo de la instancia de Olagüe, fechada en Madrid el 22 Septiembre 1960.

${ }^{73}$ Caja 4. Carpeta 'Solicitud a la Fundación Don (sic) Juan March'. Tarjeta manuscrita, fechada en Madrid ? Diciembre 1960.

${ }^{74}$ Caja 7. Carpeta 'Correspondencia Literaria II'. Tarjeta manuscrita, sin fecha, con membrete.
} 
discurso es el que sostienen los sectores académicos que fomentan las ideas de Olagüe en la actualidad, una coincidencia que no parece razonable considerar meramente casual ${ }^{75}$.

En sus siguientes intentos de publicar su trabajo en Francia, Olagüe se sirvió de la mediación del Padre Hamman ${ }^{76}$, el cual se encargó de presentarlo a dos editoriales en 1964, Editions Bernard Grasset y Desclée de Brouwer, sin resultado favorable ${ }^{77}$. Pero las negativas no desanimaban a Olagüe, el cual, a estas alturas, al parecer, había perdido las esperanzas de ver publicada su obra en España. Así, al menos, parece indicarlo su respuesta a una propuesta de colaboración para la revista Cuadernos para el Diálogo en $1964^{78}$ :

'Hace años que he desistido de escribir para editoriales o periódicos que impriman en España. La remuneración material que se percibe no compensa para un profesional de la pluma los disgustos que le proporciona la censura, lo cual se aumenta con la escasa resonancia que en estas condiciones alcanza cualquier trabajo literario o científico. Pues hace años que el público culto en nuestra tierra se desinteresa, como me pasa a mi mismo, por todo lo escrito en estas pátrias (sic) condiciones'.

Olagüe volvió a probar suerte, infructuosamente, al año siguiente en otra reputada casa francesa, Albin Michel, cuyo director literario, Robert Sabatier, explicaba la negativa de la editorial en los términos siguientes ${ }^{79}$ :

'Votre deuxième manuscrit, La révolution islamique en Occident, a fait l'objet de rapports de lecture favorables. Nos lecteurs nous ont signalé son interet sur le plan historique, mais là encore nous ne sommes pas sûrs de pouvoir le publier avec toutes les chances de succès désirables. II s'agit d'un très gros volume et le commerce de la librairie actuel est à ce point difficile, que nous ne pensons pas pouvoir rencontrer le succès avec un ouvrage dont le prix serait trop élevé pour tenter les acheteurs. D'autre part, si du point de vue historique ce livre est intéressant, nous vous signalons que le texte aurait besoin d'être revu sur le plan de l'écriture. En effet, et notamment

\footnotetext{
75 'Ser independiente en España cuesta mucho dinero, y a mí me sucede. Mi formación inicial fue apoyada por becas estatales. Pero, como he sacado la cabeza con una línea de investigación y pensamiento que no es la oficialista, desde hace 15 años que no recibo un euro de subvenciones para mi grupo de investigación (...). Los expertos de largo recorrido estamos de más, piensan que incomodamos. Porque se ha establecido que el Islam es el equivalente a los rojos de hace 50 años. En un modelo de guerra fría, se sustituye al rojo por el musulmán. Y todo aquel que argumente otros problemas y otras causas, es un tipo que está incomodando'. Entrevista a E. González Ferrín en El Correo de Andalucía, 23 Julio 2016: http://elcorreoweb.es/sevilla/europa-no-quiere-admitir-que-los-atentados-son-obra-decompatriotas-europeos-FX2022214. Acceso 24 Septiembre 2017.

${ }^{76}$ No he podido averiguar la identidad de este personaje.

${ }^{77}$ Caja 10. Carpeta 'Mezquita'. Carta de Éditions Bernard Grasset fechada en París el 21 Agosto 1964. Carta de Desclée de Brouwer fechada el 9 Septiembre 1964.

78 Caja 7. Carpeta 'Correspondencia literaria II'. Carta de Olagüe fechada en Madrid el 17 Diciembre 1964, en respuesta a la enviada por el secretario de Redacción de la revista, Pedro Altares, fechada en Madrid el 23 Noviembre 1964.

79 Caja 10. Carpeta 'Mezquita'. Carta de Olagüe fechada en Madrid el 5 Marzo 1965, indicando el envío de La révolution islamique en Occident. Nota de Albin Michel fechada en París el 9 Marzo 1965 acusando recibo de la obra. Nota de Albin Michel fechada en París el 10 Agosto 1965, rechazando la obra.
} 
dans les phrases longues, le français n'est pas toujours correct. Il s'agit là bien sûr d'un aspect secondaire et nous vous l'indiquons uniquement pour vous donner une idée des réserves qui peuvent être faites sur ce volume. Ce n'est pas sans hésitations que nous refusons cet ouvrage. Ne pourrait-il pas entrer dans le cadre du programme de l'un de nos confrères plus spécialisé, comme, par exemple, les Presses Universitaires de France?'.

De este modo, en 1965 Olagüe acumulaba seis años consecutivos de negativas a su proyecto, incluyendo a la Fundación Juan March y a cuatro importantes editoriales francesas. Su suerte solo cambiaría, una vez más, gracias al recurso a los contactos personales, en este caso del máximo nivel académico.

\section{La edición francesa: Les Arabes n'ont jamais envahi l'Espagne}

En 1969, la editorial Flammarion editó Les Arabes n'ont jamais envahi l'Espagne, viendo, así, Olagüe, coronado por el éxito su proyecto comenzado once años antes. La documentación preservada permite reconstruir con bastante detalle el proceso que condujo a la aceptación del manuscrito y a su posterior edición.

Entre dicha información, sin duda la más significativa se refiere al papel determinante desempeñado por Braudel en la publicación de la obra, algo que ya había sido apuntado con anterioridad tanto por Vincent como por Fierro (Vincent 2004, p. 18; Fierro 2009, p. 342). Aunque no conocemos de qué forma logró Olagüe acceder a una figura de tan alto nivel académico, parece que la relación entre ambos se remontaba al año 1956, según revela una carta de esa fecha del propio historiador francés en la que pone de manifiesto que previamente se produjo un encuentro personal con motivo de uno de los habituales viajes de Olagüe a París. En su carta, Braudel acusa recibo del envío de algunos de sus libros, que no duda en calificar de 'admirables' ${ }^{80}$, entre los cuales debía incluirse, sin duda, La decadencia española, que aparece citada en La Méditerranée (Braudel 1990, I, p. 250).

El dossier de correspondencia preservado, que data de $1965-1966^{81}$, revela el notable grado de confianza que Braudel llegó a depositar en Olagüe. En efecto, no sólo le ofreció la posibilidad de colaborar en la célebre y prestigiosa revista Annales, sino que, además, aceptó la propuesta que el propio autor vasco le hizo de publicar su trabajo en la colección que él dirigía en la editorial Armand Colin, llamada Destins du Monde, si bien, finalmente, el proyecto no se llevó a cabo, por motivos que no aparecen explicados en la documentación. Para convencer a Braudel, Olagüe no duda en utilizar su bien aprendido discurso victimista de autor maldito cuyas ideas eran sistemáticamente silenciadas en España ${ }^{82}$ :

'Vous serez peut-être étonné que je n'ai point publié ce texte en Espagne, comme je l'ai fait avec mes thèses sur la decadence de cette nation. Je ne vous découvrirai rien de bien nouveau, si je vous avoue que n'étant pas sympathique au régime -la litérature et la critique historique étant ici

\footnotetext{
${ }^{80}$ Caja 7. Carpeta 'Correspondencia Literaria II'. Fechada en París el 29 Noviembre 1956, mecanografiada, membrete de 'École Pratique des Hautes Études'.

${ }^{81}$ Caja 10. Carpeta 'Mezquita'.

${ }^{82}$ Carta de Olagüe fechada en Madrid el 5 Diciembre 1965, mecanografiada (dos folios).
} 
dirigées par l'Etat- on me fait un silence complet sur mon œuvre. Au temps de la Phalange j'étais un libéral, maintenant aux yeux de l'Opus Dei je suis un mécréant. Comment! Ce ne sont point les Arabes qui ont envahi l'Espagne en une poussée irrrésistible, ce sont les Espagnols qui par leur propre volonté sont passés à l'héresie unitaire et ensuite à l'Islam...!

C'est pourquoi lorsque j'ai demandé le concours de l'Institut très riche, Juan March, pour m'aider à poursuivre mes travaux, celui-ci m'a été refusé. J'ai du travailler avec mes propres moyens et les ressources d'un homme de lettres qui doit se défendre dans un milieu hostile. J'ai due voyager et réaliser plusieurs centaines de photographies avec l'aide d'un ami spécialisé, avec le seul produit de mes droits d'auteur. Enfin, j'ai réussi à achever cet ouvrage et je vous demande I'hospitalité pour son édition'.

Al margen de las razones que hiciesen fracasar la opción de Armand Colin, lo cierto es que ello no significó, en absoluto, que Braudel se desentendiese del asunto. Muy al contrario, logró que Flammarion aceptase la obra, lo cual comunica a Olagüe el 2 de febrero de $1966^{83}$, indicándole, no obstante, que debía autorizarle a corregir el texto, un hecho que, sin duda, revela un nivel notable de implicación personal en el proyecto.

La decisiva intervención de Braudel ante Flammarion queda, asimismo, ratificada por la propia correspondencia entre el responsable de la misma (Henri Noguères) ${ }^{84}$ y Olagüe ${ }^{85}$, en la que el autor vasco afirma que espera que, junto con el manuscrito, Braudel haya adjuntado la pequeña colección de fotos que debía servir para ilustrar el libro. De hecho, Noguères corrobora que Braudel había comenzado a realizar la revisión inicial del manuscrito, si bien, al parecer, por falta de tiempo, hubo de dejar esta tarea, que acabaría finalmente siendo encomendada por la editorial a Jean Baert.

En definitiva, el papel determinante de Braudel vuelve, una vez más, a acreditar el modus operandi habitual de Olagüe, consistente en servirse de personas de prestigio (tanto social como político y académico) cuya amistad y confianza procuraba ganarse como medio para acceder a la posibilidad de publicar sus trabajos. En este caso, la cuestión radica en entender cómo alguien del nivel académico de Braudel (quien llegó a ser doctor honoris causa por doce universidades, entre ellas Cambridge y Oxford) pudo sentirse interesado por la obra de Olagüe al punto de implicarse de manera personal en la difusión de sus disparatadas ideas historiográficas.

La respuesta a este interrogante no resulta fácil de establecer, a falta de una documentación más completa que permita conocer los detalles de dicha relación. A mi juicio, resulta importante aquí volver a insistir en la habilidad del autor vasco para presentarse como 'víctima del sistema'. No en

\footnotetext{
${ }^{83}$ La carta, en realidad, está fechada en 1967, pero esta fecha resulta incompatible con los datos de que disponemos, que indican que el contrato de Olagüe con Flammarion se firmó en septiembre de 1966, iniciándose seguidamente la revisión de la obra a cargo de Jean Baert.

84 'J'ai tardé à vous répondre car je voulais pouvoir prendre connaissance du manuscrit que vous aviez confié à M. Braudel avant de vous écrire'. Carta de Noguères fechada en París el 4 de julio de 1966, mecanografiada (un folio). Toda la correspondencia entre Olagüe y Flammarion se localiza en Caja 9. Carpeta 'Flammarion. Ignacio Olagüe. La Mosquée de Cordoue et la révolution islamique'.

${ }^{85}$ Carta a Noguères fechada en San Sebastián el 16 Julio 1966, manuscrita (un folio, grapada a la anterior).
} 
vano, España vivía entonces bajo una dictadura que buena parte de las elites académicas y culturales internacionales detestaba, lo cual permitiría entender que Braudel pudiese haber considerado a Olagüe como una especie de 'refugiado intelectual' del franquismo. A este respecto, debe recordarse que, al comienzo de la II Guerra Mundial, Braudel fue hecho prisionero por los alemanes y permaneció cinco años bajo arresto, en una época en la que el régimen de Franco era abiertamente pro-Nazi. Por último, es importante también tener en cuenta que Braudel siempre mantuvo fuertes lazos académicos con España, en cuyos archivos trabajó con frecuencia, llegando a ser elegido, al final de su vida, miembro del Alto Consejo Cultural Franco-Español creado en julio de $1985^{86}$.

Al margen de las causas que puedan explicar la actuación de Braudel, que tal vez la propia correspondencia del historiador francés podría desvelar, hay asimismo que tomar en cuenta que a su decidido interés debe sumarse el de Henri Noguères (1916-1990), quien precisamente en 1966 comenzó a actuar como Secretario General de Flammarion ${ }^{87}$ y que confiesa haber quedado 'cautivado' por la originalidad y solidez de la obra de Olagüe, afirmando haberla defendido de manera 'ardorosa' ante el Consejo de Dirección de la editorial ${ }^{88}$.

Como revela la documentación, el proceso de edición de Les Arabes n'ont jamais envahi l'Espagne fue largo y complejo. El contrato se envió a Olagüe en julio de $1966^{89}$ y se firmó en septiembre ${ }^{90}$, pero la obra no sería finalmente publicada hasta el 6 de noviembre de $1969^{91}$. La causa fundamental de este considerable retraso vino motivada por la exigencia de la editorial de llevar a cabo una profunda adaptación del manuscrito original a un formato accesible para el gran público. Esta labor que, en el momento del envío del contrato a Olagüe, Noguères estimó en una duración de tres meses, iba a prolongarse, finalmente, durante más de tres años. La mayor parte del dossier de correspondencia con Flammarion se refiere a cuestiones relacionadas con este proceso de adaptación del texto, que daría no pocos quebraderos de cabeza al autor vasco.

La tarea fue encomendada a Jean Baert, sobre el cual no he podido recabar ninguna información biográfica ni bibliográfica aparte de la que existe en el fondo documental. Se trataba, al parecer, de un colaborador de la editorial, al que Noguères se refiere en su primera carta a Olagüe de la forma siguiente: 'J'ai demandé à un de mes collaborateurs habituels, un garçon d'une rare érudition, et qui s'est penché, étant à l'École des Langue (sic) Orientales, sur les problèmes de notre microcosme méditerranéen, d'entreprendre ce travail ${ }^{92}$.

Ya antes de la firma del contrato, Baert se pone por vez primera en contacto con Olagüe para comunicarle que él será el responsable de llevar a cabo la revisión de su texto, informándole con total claridad que la labor que la editorial le ha encomendado consiste en reducir la extensión del

\footnotetext{
${ }^{86}$ Véase su necrológica en El País, 29 Noviembre 1985. No he podido recabar datos sobre los planteamientos ideológicos o políticos de Braudel en ninguna de las dos biografías que se le han dedicado, Daix 1995 y Gemelli 2005.

${ }^{87}$ Véase su biografía en Wikipedia: https://fr.wikipedia.org/wiki/Henri_Nogu\%C3\%A8res. Acceso 26 Septiembre 2017.

${ }^{88}$ Carta de Noguères fechada en París el 4 Julio 1966, mecanografiada (un folio a dos caras). Se trata, aparentemente, de la primera comunicación 'oficial' de la editorial con Olagüe.

${ }^{89}$ Carta de Noguères fechada en París el 21 Julio 1966, mecanografiada (un folio).

${ }^{90}$ Carta a Noguères fechada en San Sebastián el 9 Septiembre 1966, mecanografiada (un folio).

${ }^{91}$ Carta de Noguères fechada en París el 25 Septiembre 1969, mecanografiada (un folio).

92 Carta de Noguères fechada en París el 4 Julio 1966, mecanografiada (un folio a dos caras).
} 
manuscrito, incluyendo la supresión de notas y anexos, 'conformément au voeu de la maison Flammarion'93.

Por lo tanto, desde el mismo comienzo del proceso de edición Olagüe quedó informado de que la modificación de la obra no iba a consistir, simplemente, en una corrección de estilo o una mera reducción de su extensión, sino que afectaría de lleno a su contenido 'científico'. El autor parece haber aceptado esta situación, aunque, al mismo tiempo, intentó 'salvar los muebles', insistiendo en la necesidad de preservar 'la parte esencial del aparato crítico', invocando incluso, la autoridad de Braudel para convencer al editor: 'dans le cas contraire les historiens et les specialistes nous tomberont sur le dos; ce dont $\mathrm{M}$. Braudel $\mathrm{m}^{\prime}$ a dejà averti' ${ }^{94}$. Sin embargo, los ruegos de Olagüe no parecen haber causado mucho efecto, ya que la naturaleza de la labor encomendada a Baert fue ratificada con total claridad por el propio Noguères al autor ${ }^{95}$ :

'En ce qui concerne le travail confié à Jean Baert, il est bien entendu que celui-ci doit s'efforcer de préserver une alacrité de style à laquelle nous avons été, lui comme moi, sensibles. Mais les instructions que je luis ai données le conduiront néanmoins à pratiquer de sérieux allègements, tant en ce qui concerne le texte lui-même que l'appariel (sic) scientifique. La collection dans laquelle doit paraître votre livre s'adresse en effet à un public éclairé et cultivé, mais cependant assez vaste, et auquel l'ouvrage doit rester accessible'.

De esta forma, el criterio de la editorial se impuso sobre la del autor, al igual que sucedió respecto a la segunda cuestión que hubo que resolver, la del título de la obra. La decisión no se tomó casi hasta el final del proceso, pocos meses antes de la publicación. En junio de 1969 Olagüe envía a Noguères un listado que incluía seis posibles alternativas, dando a la editorial total libertad para elegir la que quisiera ${ }^{96}$ : Le Mythe de l'invasion arabe en Occident; Révolution, point d'invasion arabe en Occident; La révolution islamique en Occident; Le mystère de la Mosquée de Cordoue ${ }^{97}$; La revolution islamique et le mythe des invasions y La revolution islamique et les invasions arabes en Occidente. Flammarion descartó todas estas opciones y acuñó un título de su propia cosecha, debido a razones de naturaleza estrictamente comercial, algo que la editorial no ocultó: 'en ce qui concerne le titre, nous nous sommes finalement arrrêtés à la demande de nos services commerciaux qui fondent de grands espoirs sur votre livre et ont insisté pour que le titre soit explicite, sur ceci: Les Arabes n'ont jamais envahi l'Espagne' ${ }^{\prime 98}$.

Solventados todos los problemas, el libro pudo ser finalmente publicado a finales de 1969, fijándose la fecha del 6 de noviembre para su lanzamiento, una operación a la que la editorial quiso dar cierta relevancia, como revela el hecho de que el propio Noguères pidiese a Olagüe que intentase estar en París con tal ocasión ${ }^{99}$.

\footnotetext{
${ }^{93}$ Carta de Baert fechada en París el 15 Agosto 1966, mecanografiada (un folio), casi ilegible.

${ }^{94}$ Carta a Noguères fechada en San Sebastián el 26 Agosto 1966, mecanografiada (un folio).

${ }^{95}$ Carta de Noguères fechada en París el 5 Septiembre1966, mecanografiada (dos folios).

${ }^{96}$ Carta a Noguères fechada en Madrid el 1 Junio 1969, manuscrita (un folio).

${ }^{97}$ Olagüe pronunció una conferencia con este título en Madrid: ABC, 15 Marzo 1961.

${ }^{98}$ Carta de Noguères fechada en París el 13 Junio 1969, mecanografiada (un folio).

${ }^{99}$ Carta de Noguères fechada en París el 25 Septiembre 1969, mecanografiada (un folio).
} 
Siguiendo su costumbre, Olagüe difundió el libro entre sus ya, por entonces, numerosos contactos académicos internacionales, entre los que, significativamente, nunca hubo especialistas en historia medieval ni en estudios árabes e islámicos ${ }^{100}$. El historiador húngaro Tibor Wittman (1923$1972)^{101}$, con el que parece haber tenido una relación personal cercana, acusa recibo del envío del libro y afirma que le hará 'buena propaganda'102. Se conservan, asimismo, acuses de recibo del francés Charles Dédéyan (1910-2003) ${ }^{103}$ y el suizo Eduard Fueter (1908-1970), director de la Revue Universitaire Suisse ${ }^{104}$, con el que la relación se remontaba a años atrás ${ }^{105}$.

Olagüe también se ocupó de que el libro fuese reseñado en la prensa ${ }^{106}$, lo cual, como hemos visto, representa una constante en su trayectoria, ya que siempre pareció estar más interesado en el impacto mediático que académico de sus obras. Lo mismo hizo entre sus contactos diplomáticos, aunque no con la misma intensidad que antaño, tal vez debido a que Lojendio ya había abandonado la diplomacia para entrar en el monacato. Así consta en el caso de Antonio Serrano de Haro Mialdea, el cual, aunque no oculta que el libro le suscita ciertas 'reservas', le transmite, al mismo tiempo, su disposición a colaborar en su difusión e incluso le sugiere la idea de organizar un Simposio sobre el tema en el Instituto Hispano-Árabe de Cultura ${ }^{107}$.

\section{La edición española: La revolución islámica en Occidente}

Las circunstancias en las que se había producido la publicación de Les Arabes n'ont jamais envahi l'Espagne no podían satisfacer de forma plena las aspiraciones de Olagüe, el cual no sólo tuvo que tolerar la 'mutilación' de todo el aparato crítico del texto ${ }^{108}$, sino, además, aceptar un título que le fue impuesto por la editorial por razones puramente comerciales (si bien, en el fondo, no parece haberle desagradado del todo, como veremos más adelante). No resulta extraño, por lo tanto, que, al mismo tiempo que comenzaba el proceso de publicación de la versión francesa, el autor

\footnotetext{
${ }^{100}$ Caja 7. Carpeta 'Les Arabes. Critiques et Lettres'.

${ }^{101}$ Sobre este autor, véase Anderle 2013, pp. 27-36.

${ }^{102}$ Carta fechada el 18 Noviembre 1969. Caja 7. Carpeta 'Correspondencia Literaria I', contiene un dossier de cartas de Wittman.

${ }^{103}$ Carta fechada en París el 1 Marzo 1970.

104 Carta fechada en Neugut el 31 Enero 1970, mecanografiada (un folio a doble cara) en la que declara su admiración por la obra, pero rechaza publicar una reseña en la revista. Caja 8. Carpeta 'Correspondencia científica' incluye carta de Fueter fechada en Neugut el 19 Febrero 1970, mecanografiada ( 2 folios), en la que afirma: 'Je pense bien que vous avez documenté votre livre sur les arabes d'une manière excellente et approfondie'.

${ }^{105}$ Caja 7. Carpeta 'Correspondencia Literaria II', carta fechada en Neugut el 14 Abril 1962 (mecanografiada, un folio), revela una visita de Olagüe a Suiza. Caja 13. Carpeta 'Críticas de periódicos', contiene tarjeta de la Sociedad Suiza de Amigos de España, Portugal y América Latina con invitación a conferencia de Olagüe el 8 Marzo 1962 en Zurich, titulada 'La mezquita de Córdoba y la revolución islámica'.

106 ABC, 24 Diciembre 1969; La Vanguardia, 19 Febrero 1970. Caja 7. Carpeta 'Les Arabes. Critiques et Lettres', contiene recortes originales de estas reseñas.

107 Carta fechada en Nueva York el 9 Enero 1970, manuscrita (2 folios a ambas caras). Firmada sin indicación de nombre (no puede deducirse de la firma) pero, sin duda se trata de Antonio Serrano de Haro Mialdea, que fuera Secretario General del Instituto Hispano-Árabe de Cultura (circunstancia a la que el autor de la carta hace referencia en la misma), así como Cónsul General Adjunto en Nueva York. Citada por Fierro 2009, p. 347. Sobre el Instituto Hispano-Árabe de Cultura (ICMA), véase Hernando de Larramendi y otros 2015.

${ }^{108}$ El autor usa específicamente esa palabra. Caja 9. Carpeta 'Flammarion', carta a Baert fechada en San Sebastián el 30 Enero 1968, mecanografiada.
} 
vasco siguiera intentando encontrar en España un editor interesado en publicarlo en su integridad $^{109}$.

Para conseguir ese objetivo recurrió a su modus operandi habitual, activar sus contactos personales. En esta ocasión, su interlocutor fue José Ma de Cossío (1892-1977), con quien Olagüe se reúne en 1966 en el Café Lion de Madrid ${ }^{110}$ para pedirle que presente a Espasa-Calpe su libro ${ }^{111}$, rechazado meses después por la editorial aduciendo 'una enorme sobrecarga de originales pendientes de publicación'112.

Olagüe reactiva su empeño a partir de 1970, contando a su favor con el apoyo que significaba disponer de una versión ya editada por una importante editorial francesa. No obstante, el proceso no fue fácil. La primera negativa la obtuvo de Taurus, con un argumento muy habitual ('tenemos un programa editorial demasiado apretado') ${ }^{113}$ y similar al empleado por Espasa-Calpe ('el gran número de reimpresiones que hemos de acometer'), que rechazaba, así, por segunda vez, el proyecto $^{114}$. La misma respuesta obtuvo de Planeta, a la que propuso la edición de varias de sus obras, entre ellas Les Arabes, todas las cuales fueron rechazadas debido a que 'no se acomodan a nuestro fondo editorial ${ }^{115}$.

Hubo, en cambio, al menos tres editoriales que mostraron interés en la obra, dos de Barcelona (Kairós y Noguer) y una entidad tan importante como Alianza ${ }^{116}$, si bien la documentación no permite conocer por qué no se llegó a ningún acuerdo con las mismas. Sea de ello lo que fuere, la encargada de publicar finalmente La revolución islámica en Occidente sería Guadarrama. Olagüe les envió la versión francesa en 1970 y, aunque no queda constancia exacta de la respuesta recibida, obviamente fue positiva ${ }^{117}$.

La edición fue producto de la colaboración de Guadarrama con la Fundación Juan March, cuyo interés consta ya en $1971^{118}$. De este modo, la misma entidad que, doce años antes, había

\footnotetext{
${ }^{109}$ El dossier de esta correspondencia se encuentra en Caja 10. Carpeta 'Mezquita'.

${ }^{110}$ Este célebre café madrileño (sito en C/Alcalá) fue, en los años previos a la Guerra Civil, lugar de celebración de la tertulia 'la ballena alegre', frecuentada por falangistas como J. Miquelarena y el propio José Antonio Primo de Rivera, entre otros. Véase Carbajosa y Carbajosa 2003, pp. 199-205.

${ }^{111}$ Carta a José Ma de Cossío fechada en Madrid el 28 Noviembre 1966. Como es sabido, la editorial Espasa-Calpe había publicado a partir de 1943 la que es considerada hasta la actualidad como 'Biblia del toro', habitualmente conocida como 'El Cossío'.

112 Carta de Espasa-Calpe fechada en Madrid el 20 Marzo 1967.

${ }^{113}$ Carta de Taurus fechada en Madrid el 23 Febrero 1970.

${ }^{114}$ Carta de Espasa-Calpe fechada en Madrid el 11 abril 1970.

115 Carta de Planeta fechada en Barcelona el 16 Junio 1970. Asimismo, se conserva copia de la carta enviada por Olagüe a la editorial, fechada en Madrid el 4 Junio 1970, mecanografiada (dos folios).

${ }^{116}$ Carta de Kairós fechada en Barcelona el 2 Enero 1970. Carta de Noguer fechada en Barcelona el 9 Enero 1970. Carta de Alianza fechada en Madrid el 30 Agosto 1971.

${ }^{117}$ Carta de Guadarrama fechada en Madrid el 30 Julio 1970.

${ }^{118}$ Archivo Fundación Juan March, carta a Olagüe fechada el 25 Octubre de 1971, enviada por Antonio Iglesias Laguna (1927-1972), conocido crítico literario, a la sazón director del Servicio de Publicaciones de la Fundación, pidiéndole que se pase por la sede "a fin de que nos pongamos de acuerdo para editarlo en nuestra colección de Monografías». Ignoro si existía alguna relación entre ambos, aunque Iglesias se dirige a Olagüe en la carta como 'su buen amigo'.
} 
rechazado el proyecto, lo financiaba ahora con la, por entonces, nada desdeñable suma de 180 mil pesetas $^{119}$ :

'Ignacio Olagüe Videla, famoso por la obra Les arabes n'ont jamais envahi l'Espagne, ha sido objeto de una ayuda económica especial para la realización de un trabajo sobre La Revolución Islámica. La finalidad de esta subvención es doble: de una parte, la elaboración rigurosamente científica y completa de la tesis del Doctor Olagüe, y de otra, posibilitar que su obra se realice en lengua castellana, repatriando así este sector de su actividad estudiosa'.

Desconocemos los detalles de la concesión de esta 'ayuda económica especial' al 'doctor' Olagüe. En cualquier caso, la edición se adaptó por completo a las exigencias del autor, tanto por la inclusión de todo el aparato crítico de su estudio como por el título, que coincidía con la idea que tenía desde la época de La decadencia española, si bien llegó a sugerir la inclusión como subtítulo del de la edición francesa ${ }^{120}$ algo que, finalmente, se ha llevado a cabo en la reciente reedición de la obra realizada por Almuzara (2017).

Sin embargo, Olagüe no pudo asistir al éxito final de su largamente esperado proyecto, cuyo origen, como hemos visto, se remontaba al año 1958. El proceso de edición fue, de nuevo, bastante lento, entre otros motivos debido, al parecer, a que el autor se demoró en la entrega del manuscrito ${ }^{121}$. Olagüe llegó a terminar de corregir las pruebas ${ }^{122}$ apenas unos días antes de morir en Javea el 10 de marzo de $1974^{123}$. Ello significa que no alcanzó a ver la aparición de La revolución islámica en Occidente, cuya publicación ya registra el Boletín de la Fundación correspondiente al mes de $\mathrm{Mayo}^{124}$.

\section{La recepción de las ideas de Olagüe: la controversia con Martínez Montávez}

La recepción de las ideas negacionistas constituye un fenómeno historiográfico de cierta amplitud que, como dije al comienzo, ha sido abordado tanto por M. Fierro como por mí mismo en trabajos previos. Por lo tanto, mi objetivo aquí se reduce a analizar las reacciones del propio Olagüe ante las críticas a su obra, lo cual nos permitirá apreciar que sus peculiaridades como historiador no

119 'Anales de la Fundación Juan March, 1972', páginas 95 y 100, disponible online: http://recursos.march.es/web/prensa/anales/1972/Anales-1972-Completo.pdf. Acceso 30 Septiembre 2017. EI director de la Fundación era, desde 1970, Cruz Martínez Esteruelas (1932-2000), que ocupó altos cargos políticos durante el Franquismo, siendo Ministro en los Gobiernos de Carrero Blanco y Arias Navarro.

${ }^{120}$ Archivo Fundación Juan March, carta de Olagüe fechada en Javea el 29 Enero 1974, proponiendo añadir una faja con un subtítulo que «podría ser la traducción del título de Flammarion, No han invadido los árabes España o algo similar: Ensayo para la pretendida invasión de España por los árabes, u otra cosa».

121 Archivo Fundación Juan March, carta a la editorial Guadarrama fechada el 24 Marzo 1973, remitiendo el manuscrito de Olagüe.

${ }^{122}$ Archivo Fundación Juan March, carta de Olagüe fechada en Javea el 6 Marzo 1974, manuscrita, 'sin fuerza motriz', según confiesa el autor, confirmando el envío a Guadarrama de las pruebas corregidas.

${ }^{123}$ Véase su esquela en $A B C, 15$ Mayo 1974, donde se indica fue enterrado en el panteón familiar de San Sebastián. Desconozco las causas de su fallecimiento, aunque no parece haber padecido una larga enfermedad, ya que apenas un mes antes buscaba editor para su obra Mort et transfiguration de l'Europe. Caja 7. Carpeta 'Correspondencia Literaria I'. Carta a Librairie Arthème Fayard fechada en Javea el 7 Febrero 1974.

124 Número 27, Mayo 1974, página 189. Disponible online en la Web de la Fundación: http://recursos.march.es/web/prensa/boletines/pdf/1974/n-27-mayo-1974.pdf. Acceso 30 Septiembre 2017. La obra carece de colofón, por lo cual no resulta posible conocer la fecha exacta de impresión. 
sólo se limitan a la naturaleza de sus ideas, sino que se extienden a otros aspectos, en especial a su manera de afrontar las críticas.

La reacción de los medios académicos franceses especializados fue bastante inmediata y muy clara respecto a la verdadera naturaleza de Les Arabes n'ont jamais envahi l'Espagne. Así lo acredita, en particular, el caso de Roger Le Tourneau, el cual señalaba que la idea que con mayor claridad se desprendía de la lectura del libro es que su autor 'cherche à presenter sous une forme de démostration une réaction sentimentale de l'auteur qui ne peut pas admettre la conquête de l'Espagne par les "Maures" et cherche à minimiser autant qu'il est possible l'influence culturelle du monde Musulman sur la Péninsule ${ }^{125}$. Cuatro años más tarde, el medievalista P. Guichard publicó en Annales ESC un artículo de título elocuente ('Les Arabes ont bien envahi l'Espagne'), en el que no duda en calificar dicha obra como 'montagne de histoire-fiction', si bien es improbable que Olagüe alcanzase a tener noticia del mismo, algo que puede asegurarse en el caso de la reseña que un año más tarde apareció en el Journal of Middle East Studies por obra de J. T. Monroe, tal vez la más contundente de todas las críticas realizadas al libro del autor vasco.

Aunque no es el propósito de este trabajo profundizar en la crítica de las propuestas de Olagüe, merece la pena rescatar, por su especial significación, algunos de los comentarios del célebre arabista norteamericano, que comienza su reseña calificando la obra del autor vasco como 'not a scholarly work', en particular por lo que se refiere a la abierta acusación de antisemitismo (Monroe 1975, p. 347):

'The author rejects several centuries of serious scholarly investigation in the field of Orientalism on the grounds that the latter, in alliance with the enemies of Spain (both within and without), has traditionally been motivated by a secret desire to undermine that European, and also IndoEuropean, nation's prestige by rewriting its history to prove falsely that it has undergone a Semitic conquest. We are thus transported into the familiar realm of the Semitic plot that plagues much of Spanish historiography, and the book's underlying racism begins to become apparent'.

En España, la respuesta más importante corrió de parte de Pedro Martínez Montávez, autor de una reseña publicada el 27 de Mayo de 1971 por encargo del periódico madrileño Informaciones. No dispongo de espacio aquí para ocuparme con detalle de dicho texto, algo que ya hice en mi monografía de 2013 (García Sanjuán 2013, p. 134), pero sí conviene enfatizar la coincidencia del parecer de dicho autor con el de los colegas franceses, llegando a calificar el libro de 'historiaficción'. Su resumen final de la obra incluía las siguientes observaciones ${ }^{126}$ :

'Libro irritante en ocasiones, asombroso a veces, atisbador y sugerente en puntos concretos, no lo dudo; osado, creo que mucho menos de lo que puede, a simple vista, parecer; descabellado, creo que sí, en bastantes aspectos; personal, a-objetivo y polémico, sin duda, con evidentes visos sensacionalistas'.

\footnotetext{
125 Le Tourneau 1970, p. 195.

${ }^{126}$ Caja 7. Carpeta 'Les Arabes. Critiques et Lettres', incluye original de la reseña.
} 
La reseña, obra de un Arabista académico (por entonces Catedrático de la Universidad de Sevilla), y aparecida en un medio de comunicación de difusión nacional, provocó la reacción inmediata de Olagüe, quien se puso en contacto con el director del periódico, Jesús de la Serna, hijo de su amigo Víctor de la Serna, como el propio autor vasco se encargó de recordarle al comienzo de la carta que le envió solo dos días después de la aparición de la reseña, pidiéndole que le abriera las páginas del periódico para responder a Martínez Montávez.

El texto apareció a los pocos días (10 junio) bajo el título de 'Ignacio Olagüe contesta a Martínez Montávez ${ }^{127}$. Se trata de un testimonio de extraordinario interés, ya que fue la única ocasión en la que el autor vasco respondió de forma pública a las críticas recibidas. Olagüe vuelve a exhibir su amateurismo, ahora a través de su escaso talante académico, en particular por lo que se refiere a la manera de calificar a sus distintos críticos, basada en un evidente doble rasero no exento de notorias dosis de cinismo. En efecto, para desautorizar a Martínez Montávez, Olagüe no duda en acudir, entre otros, al argumento de su falta de especialización en el tema del libro:

'En ciencias históricas como en las demás, la autoridad se alcanza con el peso de la obra publicada sobre los asuntos objeto de discusión. Y hasta la fecha -por lo menos en los casos en los que nos hemos dedicado a estos estudios- no hemos tenido conocimiento de trabajo alguno sobre este tema publicado por el señor Martínez Montávez'.

Esta valoración del perfil académico de dicho arabista llama poderosamente la atención. En efecto, no sólo procede de un aficionado carente de cualificación como historiador y claramente incapaz de interpretar de forma rigurosa las fuentes históricas. Peor aún, se trata de un juicio que revela fuertes dosis de cinismo, ya que, cuando valora las opiniones favorables a sus postulados, Olagüe no sólo prescinde por completo del requisito de la especialización, sino que convierte en expertos a quienes, en modo alguno, podrían ser considerados como tales. Así lo indica la relación de 'autoridades' a las que se remite para ensalzar su obra, ninguna de las cuales reúne los más mínimos requisitos para ser calificada, no ya como especialista en la conquista musulmana, sino ni siquiera como historiador o arabista, tal vez con una única excepción. Entre ellos, el autor vasco destaca, en particular, a 'autoridades en la civilización arábiga como el señor Raymond Charles, maestro mundialmente conocido en Derecho musulmán, y especialistas en la Alta Edad Media, como Emmanuel Berl, que me ha escrito acerca de la batalla de Poitiers ${ }^{\prime 28}$.

De entrada resulta llamativo que, en un debate historiográfico, se invoque la opinión de un tercero formulada a través de una comunicación personal. Al margen de ello, huelga decir que ninguna de las dos 'autoridades' citadas por Olagüe podría, en ningún caso, ser considerada como tal. Emmanuel Berl es alguien suficientemente conocido como para tener que detallar aquí su perfil, ajeno por completo a los estudios medievales y, más aún, a los estudios islámicos (Morlino 1990).

El caso de Charles es, con toda probabilidad, el que mejor retrata la actitud de Olagüe. En efecto, este autor había publicado sendos libros de tema islámico, bajo el título de L'âme musulmane

\footnotetext{
${ }^{127}$ Caja 7. Carpeta 'Les Arabes. Critiques et Lettres'. Incluye copia de la carta de Olagüe a Jesús de la Serna, respuesta de éste (fechada en Madrid el 1 Junio 1971) y tres originales de la réplica de Olagüe.

${ }^{128}$ Caja 7. Carpeta 'Les Arabes', contiene carta manuscrita de Berl, sin fecha (dos folios), en la que acusa recibo de la obra de Olagüe y se muestra completamente a favor de sus ideas: 'Je ne doute pas que vous avez raison. Le simple bon sens et un minimum de réflexion avaient suffi pour me faire ranger la bataille de Poitiers parmi "les impostures de l'Histoire". Vos admirables travaux fournissent la preuve de ce qui était évident'.
} 
(1958) y L'évolution de l'Islam (1960), si bien se trata de obras secundarias y de escasa difusión e influencia ${ }^{129}$. Por lo tanto, difícilmente podría ser calificado como una 'autoridad', algo que ratifica su propia reseña del libro, aparecida en La vie judiciaire, un simple boletín semanal que ni siquiera cabría considerar como una revista académica de Derecho. De hecho, antes de que la escribiera, Olagüe no había escuchado jamás hablar de este 'maestro mundialmente conocido en Derecho musulmán', cuya mera afiliación profesional desconocía, tal y como revela en una carta dirigida a Flammarion ('magistrat, je crois, à la court d'appel de Paris') ${ }^{130}$. Con posterioridad entró en contacto directo con Charles, ya que entre sus papeles se conserva un ejemplar original de dicha reseña ${ }^{131}$, seguramente enviada por el propio autor, así como una nota manuscrita, probablemente también suya ${ }^{132}$.

Pero Olagüe no sólo no dudaba en inventarse, literalmente, a 'expertos mundiales' en historia del Islam, sino que soslayaba la opinión de los verdaderos especialistas, tal y como el propio Martínez Montávez le indicaba en la contrarréplica que publicó en el mismo diario, unos días más tarde ${ }^{133}$. A este respecto, resulta significativo que Olagüe, con su habitual pomposidad y desparpajo, proclamara que 'han sido unánimes los autores de dichas críticas en aceptar favorablemente mis tesis'. Teniendo en cuenta la relevancia de Le Tourneau ${ }^{134}$ y los habituales contactos de Olagüe con el mundo académico francés, no parece lógico pensar que hubiese podido desconocer su texto.

De hecho, no es la única reseña que Olagüe omitió en su réplica, ya que tampoco menciona la de René Cotrait (1931-1975), de la cual poseía una copia que consta en el dossier. Resulta más que probable que la razón de dicha omisión radique, sencillamente, en que no fue de su agrado, debido a que Cotrait criticaba un aspecto también comentado por Martínez Montávez, provocando el enfado de Olagüe: 'comprendo que le haya molestado la ausencia en mi recensión de la menor alusión al importante aparato crítico de su libro todavía sin editar, y confieso que lleva razón ${ }^{\prime 35}$.

Por lo demás, aparte de Charles y Berl, llama la atención comprobar que las restantes 'autoridades' que Olagüe aduce a su favor son simples comentarios o recensiones periodísticas publicados, además, en medios de comunicación secundarios, con excepción del caso de Le Figaro

\footnotetext{
${ }^{129}$ Síntoma de ello es que dichas obras solo fueron objeto de muy escuetas recensiones en revistas no especializadas, tanto que sus respectivos autores ni siquiera se identifican, salvo en un caso: Population 15-3 (1960), 557-558 y 15-5 (1960), 911; Mayeux 1959, p. 177.

${ }^{130}$ Caja. Carta de Olagüe fechada en Madrid el 26 Febrero 1970, mecanografiada (un folio).

${ }^{131}$ Caja 7. Carpeta 'Les Arabes. Critiques et Lettres', incluye copia de dicha reseña, acompañada de tarjeta del propio autor con membrete de 'Conseiller Honoraire à la Cour de Casation', fechada el 30 Marzo 1970.

132 Caja 7. Carpeta 'Correspondencia Literaria II', con membrete 'Cour de Cassation', fechada en París el 29 Abril 1970, sin indicación de remitente y con firma ilegible, cuyo autor agradece a Olagüe el envío de La decadencia española.

${ }^{133}$ Caja 7. Carpeta 'Les Arabes. Critiques et Lettres', contiene recorte de prensa original de este texto, sin fecha.

${ }^{134}$ Sobre Le Tourneau, véase la necrológica de Adam 1973, pp. 9-13.

135 Caja 7. Carpeta 'Les Arabes'. Reseña publicada en Bulletin d'Information du Centre de Documentation et de Recherches Bibliographiques. La carta de Cotrait a Olagüe está fechada el 16 Noviembre 1970, manuscrita (un folio) y en ella afirma (en español): 'comprendo que le haya molestado la ausencia en mi recensión de la menor alusión al importante aparato crítico de su libro todavía sin editar', si bien, al mismo tiempo, valora 'el carácter nuevo y excitante de su tesis'. Sobre Cotrait, véase Bonneville 1976, pp. 212-214.
} 
(27 Enero 1970): se trata de G. Frameries (Populaire), André Toledano ${ }^{136}$ (La Croix), G. GuitardAubisque (Les Nouvelles Littéraires), E. Simon (Jeune Afrique) y J. Schmidt (La Réforme) ${ }^{137}$.

En definitiva, la controversia con Martínez Montávez pone de manifiesto, de nuevo, el amateurismo de Olagüe como historiador y su forma de afrontar las críticas, muy alejada de los parámetros habituales rigen los debates académicos. Su evidente afán por magnificar las valoraciones extraacadémicas y no especializadas de su obra se combina con su desdén hacia las opiniones de los especialistas (Martínez Montávez) o su ignorancia absoluta de las mismas (Le Tourneau). Todo ello nos sitúa, una vez más, ante el perfil de un historiador aficionado no exento de actitudes oportunistas.

\section{Reflexión final}

El análisis exhaustivo de la documentación personal de Ignacio Olagüe, depositada en la Casa de Velázquez, representa la principal fuente de información para conocer el desarrollo del proyecto historiográfico del autor. A través de su correspondencia resulta posible analizar con cierto detalle los mecanismos utilizados por Olagüe para dar forma a sus ideas historiográficas, la más importante y conocida de las cuales se refiere a la revisión del origen de al-Andalus y a la negación de la existencia de un proceso de conquista protagonizado por contingentes árabes y beréberes que actuaban al servicio del Califato Omeya de Córdoba.

La documentación preservada revela el amateurismo del autor derivado, fundamentalmente, de su falta absoluta de formación especializada como historiador, hecho que con toda probabilidad explica sus escasas relaciones con sectores historiográficos académicos en España. En cambio, Olagüe poseía importantes contactos en sectores diplomáticos y periodísticos, de los cuales se sirvió de forma sistemática para difundir su proyecto historiográfico, tanto dentro como fuera de España. Asimismo, gracias a su buen dominio del francés, logró establecer relaciones académicas de alto nivel en el extranjero, en particular por lo que se refiere a la figura de F. Braudel, cuya intervención resultó determinante para la publicación de Les Arabes n'ont jamais envahi l'Espagne. La correspondencia con el célebre historiador francés revela con total claridad la naturaleza decisiva de su actuación ante la editorial Flammarion, entidad responsable de la edición de dicha obra, así como las complejas vicisitudes de su publicación final.

La aparición de la versión francesa del manifiesto negacionista de Olagüe fue recibida con durísimas críticas desde el mundo académico especializado, tanto en Francia (R. Le Tourneau, P. Guichard) como en España (P. Martínez Montávez) y EEUU (J. T. Monroe). Las reseñas publicadas por dichos autores denunciaban la naturaleza infundada y completamente acientífica de tales propuestas, así como las connotaciones racistas que subyacen a las mismas. La reacción del Olagüe ante dichas críticas vuelve a poner de manifiesto su evidente amateurismo, así como su

\footnotetext{
136 Parece tratarse del único autor de esta relación con cierto perfil académico, ya que habría sido secretario del Centre international de synthèse fundado en 1925 por Henri Berr (1863-1954): véase Dumoulin 2003, p. 81. En su ficha de la Bibliotèque National de France se le menciona como 'Ancien professeur de langue et de civilisation espagnoles à I'École libre des sciences politiques' y 'Ancien professeur à l'Institut supérieur d'interprétation et de traduction de I'Institut catholique de Paris': http://data.bnf.fr/12455362/daniel_andre_toledano/. Acceso 30 Septiembre 2017. En Caja 7. Carpeta 'Correspondencia literaria II', se incluyen dos cartas manuscrita de Toledano, fechadas en Le Havre el 9 Enero y el 13 Febrero 1970.

${ }^{137}$ Caja 7. Carpeta 'Les Arabes. Critiques et Lettres', incluye copias y originales de todos estos textos.
} 
desconexión respecto a las prácticas académicas más elementales, en particular por lo que se refiere a su controversia en España con Martínez Montávez. Soslayando las críticas formuladas por dicho arabista en un medio de comunicación de la época y mostrando notables dosis de cinismo, Olagüe se justifica en la opinión de supuestos 'expertos', ninguno de los cuales, en realidad, reúne condiciones aceptables para ser calificado como tal, tratándose de simples recensiones periodísticas publicadas en medios de comunicación secundarios.

Pese a la amplia indiferencia con que dicha obra fue recibida en España, Olagüe logró finalmente realizar su proyecto historiográfico, centrado en la consecución de una edición española íntegra de sus ideas sobre los orígenes de al-Andalus. La publicación en 1974 de La revolución islámica en Occidente por la Fundación Juan March culminaba, así, un largo proceso iniciado a comienzos de la década de 1950, si bien el autor fallecería unas semanas antes de la aparición de la obra.

\section{Bibliografía}

ADAM, André (1973), "Roger Le Tourneau (1907-1971)", Revue de l'Occident musulman et de la Méditerranée, 13-1, pp.

9-13.

https://doi.org/10.3406/remmm.1973.1187

ANDERLE, Ádám (2013), "Tibor Wittman en la historiografía húngara", Öt Kontinens, pp. 27-36. BONNEVILLE, Henry (1976), "René Cotrait (1931-1975)", Bulletin Hispanique, 78-1, pp. 212-214. BOSQUE MAUREL, Joaquín (1981), "Jean Sermet, Geógrafo andalucista”, Cuadernos Geográficos de la Universidad de Granada, 11 (dedicado al Profesor Jean Sermet), pp. 11-42.

BRAUDEL, Fernand (1990), La Méditerranée et le monde méditerranéen à l'époque de Philippe II, Armand Colin, París, 9a ed., 2 vols.

CARBAJOSA, Mónica y CARBAJOSA, Pablo (2003), La corte literaria de José Antonio: la primera generación cultural de la Falange, Crítica, Barcelona.

CASANOVA, Julián (2007), República y guerra civil, J. Fontana y R. Villares (directores), Historia de España, vol. 8. Crítica y Marcial Pons.

CHARLES, Raymond (1970), Reseña de Les Arabes n'ont jamais envahi l'Espagne, La vie judiciaire, no 1244, 9-15 febrero, pp. 1-6.

DAIX, Pierre (1995), Braudel, Flammarion, París.

DELAUNAY, Jean-Marc (1994), Des palais en Espagne. L'École des hautes études hispaniques et la Casa de Velázquez au coeur des relations franco-espagnoles du XXe siècle (1898-1979), Casa de Velázquez, Madrid.

DUMOULIN, Olivier (2003), Marc Bloch o el compromiso del historiador, Universidad de Valencia y Universidad de Granada.

FERNÁNDEZ FERNÁNDEZ-CUESTA, Juan Manuel (2016), "Luis María de Lojendio, portavoz de la política exterior española en la Guerra Fría. Un viaje personal desde el primer al último franquismo", Hispania Nova, 14, pp. 213-228.

FIERRO, Maribel (2009), "Al-Andalus en el pensamiento fascista. La revolución islámica en Occidente de Ignacio Olagüe", en M. Marín (ed.), Al-Andalus/España. Historiografías en contraste, siglos XVII-XXI, Casa de Velázquez y CSIC, Madrid, pp. 325-349.

FUSI, Juan Pablo (1999), Un siglo de España: la cultura, Marcial Pons, Madrid.

GALLEGO, Ferrán (2005), Ramiro Ledesma Ramos y el fascismo español, Síntesis, Madrid. 
GARCÍA SANJUÁN, Alejandro (2018a), "El origen de al-Andalus en el discurso españolista: catastrofismo y negacionismo en torno a la conquista musulmana de la península ibérica", en $E I$ islam: pasado de un futuro. XXVIII Semana de Estudios Medievales (Nájera, 24-28 Julio 2017), Universidad de La Rioja, Logroño, pp. 37-65.

GARCÍA SANJUÁN, Alejandro (2018b), "La creciente difusión de un fraude historiográfico: la negación de la conquista musulmana de la península ibérica", Vínculos de Historia, 7 (en prensa).

GARCÍA SANJUÁN (2013), Alejandro, La conquista islámica de la península ibérica y la tergiversación del pasado: del catastrofismo al negacionismo, Marcial Pons, Madrid.

GEMELLI, Giuliana (2005), Fernand Braudel, Universidad de Granada.

GONZÁLEZ FERRÍN, Emilio (2017), Cuando fuimos árabes, Almuzara, Córdoba.

GONZÁLEZ FERRín, Emilio (2006), Historia general de Al Andalus, Almuzara, Córdoba.

GUICHARD, Pierre (1974), "Les Arabes ont bien envahi l'Espagne: les structures sociales de l'Espagne musulmane", Annales. Économies, Sociétés, Civilisations, Volume 29 Numéro 6, pp. 1483-1513. https://doi.org/10.3406/ahess.1974.293575

HERNANDO DE LARRAMENDI, Miguel y otros (coord.) (2015), El Instituto Hispano-Árabe de Cultura: orígenes y evolución de la diplomacia pública española hacia el mundo árabe, Agencia Española de Cooperación Internacional para el Desarrollo, Madrid.

LE TOURNEAU, Roger (1970), Reseña de Les Arabes n'ont jamais envahi l'Espagne, Revue de l'Occident musulman et de la Méditerranée, 8-1, pp.193-195.

MARTÍNEZ MONTÁVEZ, Pedro (1971a), "Los árabes no invadieron España", Informaciones, 27 Mayo.

MARTÍNEZ MONTÁVEZ, Pedro (1971b), “Martínez Montávez responde a Olagüe”, Informaciones, ?. MAYEUX, Marie-Rose (1959), Reseña de Ch. Raymond, L'Ame musulmane, Archives de sociologie des religions, 8-1, p. 177.

MOLL, Jaime (1980), "Les éditions de Quevedo dans la donation Olagüe à la bibliothèque de la Casa de Velázquez", Mélanges de la Casa de Velázquez, 16-1, pp. 457-494. https://doi.org/10.3406/casa.1980.2336

MONROE, James T. (1975), Reseña de Les Arabes n'ont jamais envahi l'Espagne, International Journal of Middle East Studies, 6-3, pp. 347-348.

MORLINO, Bernard (1990), Emmanuel Berl: les tribulations d'un pacifiste, La Manufacture, París.

OLAGÜE, Ignacio (2017), La revolución islámica en Occidente, Almuzara, Córdoba.

OLAGÜE, Ignacio (2004), La revolución islámica en Occidente, Plurabelle, Córdoba.

OLAGÜE, Ignacio (1974), La revolución islámica en Occidente, Fundación Juan March, Madrid.

OLAGÜE, Ignacio (1971), "Ignacio Olagüe contesta a Martínez Montávez", Informaciones, 10 Junio.

OLAGÜE, Ignacio (1969), Les Arabes n'ont jamais envahi l'Espagne, Flammarion, París.

OLAGÜE, Ignacio (1950-1951), La decadencia española, Mayfe, Madrid, 4 vols.

OLAGÜE, Ignacio (1939), La decadencia española, Librería Internacional, San Sebastián.

PASAMAR, Gonzalo y PEIRÓ, Ignacio (2002), Diccionario de historiadores españoles contemporáneos, Akal, Madrid.

RODRÍGUEZ PUÉRTOLAS, Julio (2008), Historia de la literatura fascista española, Akal, Madrid, 2 vols.

SÁEZ, Emilio y ROSSELL, Mercè (1976-1985), Repertorio de medievalismo hispánico (1955-1975), EI Albir, Barcelona, 4 vols.

TRUYOLS SANTOJA, Jaime y otros (coord.) (2004), Homenaje a José Royo Gómez, 1895-1961, Generalitat Valenciana, Valencia.

VINCENT, Bernard (2004), "Introducción", en Olagüe, Ignacio, La revolución islámica en Occidente, Plurabelle, Córdoba, pp. 15-19. 